\title{
Impact of Some Antibiotics on Bacteria Isolated from Appendices in Kirkuk Province, Iraq
}

\author{
Ayoub A. Bazzaz ${ }^{*}$, Diyari A. K. Lor ${ }^{2}$, Najdat B. Mahdi² \\ ${ }^{1}$ Department of Basic Science, Faculty of Dentistry, University of Kirkuk, Kirkuk, Iraq \\ ${ }^{2}$ Department of Biology, Faculty of Sciences, University of Kirkuk, Kirkuk, Iraq \\ Email: *ayoubbazzaz@yahoo.co.uk
}

How to cite this paper: Bazzaz, A.A., Lor, D.A.K. and Mahdi, N.B. (2018) Impact of Some Antibiotics on Bacteria Isolated from Appendices in Kirkuk Province, Iraq. $A d$ vances in Bioscience and Biotechnology, 9, $1-10$.

https://doi.org/10.4236/abb.2018.91001

Received: December 9, 2017

Accepted: January 16, 2018

Published: January 19, 2018

Copyright $\odot 2018$ by authors and Scientific Research Publishing Inc. This work is licensed under the Creative Commons Attribution International License (CC BY 4.0).

http://creativecommons.org/licenses/by/4.0/

\section{(c) (i) Open Access}

\begin{abstract}
A bacteriological study of 50 appendectomy cases for patients diagnosed by physicians to be appendicitis, within Kirkuk province was carried out to isolate the habitat bacteria of appendix and to assess the impact of some antibiotics on isolated bacterial species from the appendices. The age of patients ranged between 3 - 45 year old ( 21 male and 29 female). The culture results showed $94 \%$ single isolate with $2 \%$ negative growth and $4 \%$ mixed growth were obtained. The gram positive bacteria isolate formed $(11.77 \%)$ less than gram negative $(88.23 \%)$. The total isolates represented 51 included Escherichia coli 34 (66.66\%), followed by Enterococcus faecalis 3 (5.89\%), Klebsiella pneumonia 3 (5.89\%), Citrobacter youngae 2 (3.92\%), Raultella terrigena 2 (3.92\%), Pseudomonas aeruginosa 2 (3.92\%), Enterrobacter cloacae 1 (1.96\%), Serratia fonticola 1 (1.96\%), Entercoccus faecium 1 (1.92\%), Staphylococcus epidermides 1 (1.96\%) and Staphylococcus xylosus 1 (1.96\%). The Staphylococcus xylosus was the first time to be isolated in Kirkuk city while both of Raultella terrigena and Citrobacter youngae were isolated for the first time in appendix samples. Only 16 various antibiotics were tested against Enterobacteriaceae and Pseudomonas aeruginosa while 12 and 7 against Staphylococcus $s p$. and Enterococcus sp., respectively. The Imipenem and Amikacin were found to be most effective antibiotics against all Enterobacteriaceae isolates and Pseudomonas aeruginosa while Ampicillin, Piperacillin, Ceftazidime, Augmentin, and Cephalothin were ineffective against all isolated bacteria. The Penicillin and Vancomycin were effective against gram positive bacteria.
\end{abstract}

\section{Keywords}

Bacteria, Antibiotics, Appendix, Appendectomy, Iraq

\section{Introduction}

The human appendix functions as a reservoir of beneficial microbes that can be 
used to recover some clinical events, i.e. pathogen colonization, diarrheal disease, or antibiotic treatment [1] [2]. In human, whenever the appendix is infected for any known or unknown reasons, leads to appendicitis, e.g. acute appendicitis or non-acute cases, could cause severe abdominal pain which requires surgical appendectomy as a standard choice of treatment [3] [4]. In some most recent literatures, the acute inflammation is classified as non-complicated appendicitis-inflamed appendix, in the absence of gangrene, perforation, or abscess around the appendix and complicated appendicitis-perforated or gangrenous appendicitis or the presence of peri-appendicular abscess [5] [6]. There are two important components to the pathogenesis of acute appendicitis, i.e. obstruction of the appendix and infection by primary pathogenic micro-organism. Bacterial infection is believed to be central to appendix inflammation [7]. Some bacteria may pass the intact appendiceal wall prior to perforation, while progressive infection and subsequent tissue damage with necrosis allows bacteria to move into the peritoneal cavity [8]. Several reports revealed the importance of bacteria particularly Escherichia coli and Bacteroides spp. in the pathogenesis of appendicitis [9] [10] [11] [12]. The most common organisms present are a mixture of Escherichia coli, Enterococci, Anaerobic cocci together with Bacteroides fragilis and Clostridium perfringens, which all are normally present in the lumen of the appendix [13]. Recently 32.4\% Escherichia coli, 18.9\% Bacteroides spp, 16.2\% Klebsiella pneumoniae, 9.9\% Pseudomonas aeruginosa, 6.3\% Citrobacter freundii, 4.5\% Salmonella typhi, 4.5\% Proteus mirabilis, 3.6\% Enterobacter aerogenesa, 1.8\% Peptostreptococcus, 0.9\% Staphylococcus aureus and 0.9\% Clostridium perfringns bacteria were isolated [14]. Recently, cases of appendicitis had dramatically increased, e.g. 250,000 in USA and 40,000 cases in England are reported each year [15], while a new study in Spain found a rather decrease in appendicitis in the last 10 year [16]. A total of 2375 cases, in year 2013 were reported in public hospitals of Qatar [17].

Due to the lack of bacteriological study of surgically removed appendix within Kirkuk province, this study was performed to isolate various types of bacterial species habitats in the appendix and to assess the effects of various antibiotics on them.

\section{Materials and Methods}

Fifty sample of appendix were collected from the patients with suspected appendicitis was admitted to the Azadi Hospital, Kirkuk city. Directly, after the operation the samples placed in $1 \mathrm{~mL}$ of normal saline $0.9 \%$ within a sterile screw-capped container containing. Samples then were transported from the hospital directly to the research laboratory. Inside the hood 1 gram of sample was taken and crushed by a sterile scalpel inside sterile Petri dish and then placed in screw-capped glass tubes contain brain heart infusion broth, the tubes were incubated at $37^{\circ} \mathrm{C}$ for $24 \mathrm{hrs}$. Vortex was used to homogenize bacteria in the media, then were cultured onto either MacConkey agar, Blood agar and 
Chocolate agar by streaking method. The inoculated plates were incubated aerobically for 24 hour at $37^{\circ} \mathrm{C}$ followed by examination. When no growth was detected then the plates were re-incubated for another 24 hours before discarding them as negative result. Identification of these bacteria was based on colony morphology on MacConkey agar plates, gram stain and the biochemical test including catalase, oxidase, indole, methyl red, Voges-Prauskaur, citrate utilization, motility, and Kiliger Iron Agar (KIA). However, for accurate diagnosis Api 20E (Biomerieux Co.) was used for gram negative identification. The Staphylococcus sp. was identified by Vitek2 system and Api Staph (Biomerieux Co.) while the Enterococcus sp. was identified by Lancefield grouping (Oxoid, UK) test and Vitek2 system. To assess the potency of various antibiotics for their antimicrobial sensitivity a total of 22 antibiotics were chosen to test using Kirby-Bauer Disc and were compared with those of Clinical and Laboratory Standards Institute [18]. Only 16 antibiotics were used against Enterobacteriaceae and Pseudomonas aeruginosa while 12 and 7 were used against Staphylococcus sp. and Enterococcus sp., respectively. There are some more culturing techniques like anaerobic but, was not employed due to, unfortunately, facility limitation of our laboratories.

\section{Results}

\subsection{Bacterial Isolates}

Out of fifty appendices encountered in this project only 47 (94\%) specimens were single growth, another specimen (2\%) showed negative growth and two specimens (4\%) showed mixed growth, e.g. Klebsiella pneumoniae with Enterococcus faecalis and Escherichia coli with Raoultella terrigena. The highest percentage of bacteria isolated from the appendix represented Escherichia coli 34 (66.66\%), followed by Enterococcus faecalis 3 (5.89\%), Klebsiella pneumoniae 3 (5.89\%), Citrobacter youngae 2 (3.92\%), Raultella terrigena 2 (3.92\%), Pseudomonas aeruginosa 2 (3.92\%), Enterrobacter cloacae 1 (1.96\%), Serratia fonticola 1 (1.96\%), Entercoccus faecium 1 (1.96\%), Staphylococcus epidermides 1 (1.96\%) and Staphylococcus xylosus 1 (1.96\%), respectively (Table 1). The gram positive bacteria represented (11.77\%) less than gram negative enteric bacilli which are lactose fermenter or late lactose fermenter except Pseudomomnas aeruginosa.

\subsection{The Antibiotics}

The Imipenem (IPM) and Amikacin (AK) were found to be most effective antibiotics against $E$. Coli, $K$. pneumoniae, E. cloacae, $C$. youngae, $R$. terrigena, $S$. fonticola and $P$. aeruginosa while Ampicillin (AM), Piperacillin (PRL), Ceftazidime (CAZ), Augmentin (AMC), and Cephalothin (CL) were ineffective against all isolate. All isolates of E. coli were $100 \%$ sensitive to IPM, Tobramycin (TM), AK, but showed a little less sensitivity to Chloramphenicol (C), moderately sensitive to both Ciprofloxacin (CIP) and Gentamicin $(\mathrm{CN})$ and less sensitive to 
Table 1. Types of bacteria isolated, frequency and percentage in both male and female.

\begin{tabular}{ccccccc}
\hline \multirow{2}{*}{ Gender } & \multicolumn{2}{c}{ Male } & \multicolumn{2}{c}{ Female } & $\begin{array}{c}\text { Total } \\
\text { Isolates }\end{array}$ & $\%$ \\
\cline { 2 - 6 } Bacteria & No. & $\%$ & No. & $\%$ & No. & \\
\hline Escherichia Coli & 15 & 44.1 & 19 & 55.9 & 34 & 66.66 \\
Serratia fonticola & 0 & 0.0 & 1 & 100 & 1 & 1.96 \\
Pseudomonas aeruginosa & 1 & 50.0 & 1 & 50.0 & 2 & 3.92 \\
Klebsiella pneumonia & 1 & 33.3 & 2 & 66.7 & 3 & 5.89 \\
Staphylococcus epidermides & 0 & 0.0 & 1 & 100 & 1 & 1.96 \\
Enterococcus faecium & 0 & 0.0 & 1 & 100 & 1 & 1.96 \\
Enterococcus faecalis & 0 & 0.0 & 3 & 100 & 3 & 5.89 \\
Citrobacter youngae & 2 & 100 & 0 & 0.0 & 2 & 3.92 \\
Enterobacter cloacae & 0 & 0.0 & 1 & 100 & 1 & 1.96 \\
Staphylococcus xylosus & 1 & 100 & 0 & 0.0 & 1 & 1.96 \\
Raoultella terrigena & 1 & 100 & 1 & 100 & 2 & 3.92 \\
Total & 21 & 42.0 & 30 & 58.0 & 51 & 100 \\
\hline
\end{tabular}

both Aztreonam (ATM) and Cefixime (CFM) and even lower sensitivity to both Tetracycline (TE) and to Co-trimoxazole (TS). The Klebsiella pneumoniae was highly sensitive to IPM, TM, AK, C, CIP, CFM and Cefotaxime (CTX), but moderately sensitive to ATM, CN, TE and TS. Simiarly, the Enterobacter cloaca (single isolate) was $100 \%$ sensitive to IPM, TM, AK, C, CIP, CFM, CTX, ATM, $\mathrm{CS}$ and $\mathrm{CN}$. On the other hand, the Citrobacter youngae was sensitive to IPM, TM, AK, TE and CIP but resistant to other antibiotics. The bacteria Raoultella terrigena was $100 \%$ sensitive to IPM, TM, AK, C, CIP, CFM, CTX, ATM, TE and TS but showed $50 \%$ sensitivity to CN. Similarly, the Serratia fonticola was $100 \%$ sensitive to IPM, TM, AK, C, CIP, CFM, CTX, ATM and CN. However, the bacteria Pseudomonas aeruginosa showed $100 \%$ sensitivity against IPM, AK, C and CIP but 50\% against TM (Table 2).

Enterococcus faecalis showed high sensitivity against Vancomycin (VA), and Penicillin (P); however, it displayed moderate sensitivity against AM with lesser sensitivity to both Rifampin (RA) and Doxycycline (DO), while it was resistant to Erythromycin (E). Finally, the Enterococcus faecium was highly sensitive against VA, P, and C while it showed resistant to others. Both Staphylococcus epidermides and Staphylococcus xylosus were fully sensitive to VA, P, CN, CIP, C, RA, TE, AK and TS while the $S$. xylosus showed highly sensitivity to Clindamycin (CC); however, the bacteria $S$. epidermides showed resistant to it. The $S$. epidermides was sensitive to TM while $S$. xylosus showed resistant to it (Table 3).

\section{Discussion}

Approximately one thousand different types of microbes coexist harmoniously 
Table 2. Antibiotic susceptibility test for Enterobacteriaceae and Pseudomonas aerogenosa.

\begin{tabular}{|c|c|c|c|c|c|c|c|c|c|c|c|c|c|c|}
\hline \multirow{2}{*}{$\begin{array}{l}\text { Antibiotics } \\
\text { Bacteria }\end{array}$} & \multicolumn{2}{|c|}{$\begin{array}{c}\text { E. Coli } \\
(\mathrm{N}=34)\end{array}$} & \multicolumn{2}{|c|}{$\begin{array}{l}K \cdot \text { pneumoniae } \\
(\mathrm{N}=3)\end{array}$} & \multicolumn{2}{|c|}{$\begin{array}{l}\text { E. cloacae } \\
(\mathrm{N}=1)\end{array}$} & \multicolumn{2}{|c|}{$\begin{array}{l}\text { C. youngae } \\
\qquad(\mathrm{N}=2)\end{array}$} & \multicolumn{2}{|c|}{$\begin{array}{l}\text { R. trrigena } \\
\qquad(\mathrm{N}=2)\end{array}$} & \multicolumn{2}{|c|}{$\begin{array}{l}\text { S. fnticola } \\
(\mathrm{N}=1)\end{array}$} & \multicolumn{2}{|c|}{$\begin{array}{l}\text { P. aeuginosa } \\
\qquad(\mathrm{N}=2)\end{array}$} \\
\hline & $\mathrm{N}$ & $\%$ & $\mathrm{~N}$ & $\%$ & $\mathrm{~N}$ & $\%$ & $\mathrm{~N}$ & $\%$ & $\mathrm{~N}$ & $\%$ & $\mathrm{~N}$ & $\%$ & $\mathrm{~N}$ & $\%$ \\
\hline $\mathrm{AK}$ & 34 & 100 & 3 & 100 & 1 & 100 & 2 & 100 & 2 & 100 & 1 & 100 & 2 & 100 \\
\hline $\mathrm{AMC}$ & 0 & 0 & 0 & 0 & 0 & 0 & 0 & 0 & 0 & 0 & 0 & 0 & 0 & 0 \\
\hline $\mathrm{AM}$ & 0 & 0 & 0 & 0 & 0 & 0 & 0 & 0 & 0 & 0 & 0 & 0 & 0 & 0 \\
\hline ATM & 14 & 41.2 & 2 & 66.7 & 1 & 100 & 0 & 0 & 2 & 100 & 1 & 100 & 0 & 0 \\
\hline CFM & 14 & 41.2 & 3 & 100 & 1 & 100 & 0 & 0 & 2 & 100 & 1 & 100 & 0 & 0 \\
\hline CAZ & 0 & 0 & 0 & 0 & 0 & 0 & 0 & 0 & 0 & 0 & 0 & 0 & 0 & 0 \\
\hline CTX & 9 & 26.5 & 3 & 100 & 1 & 100 & 0 & 0 & 2 & 100 & 1 & 100 & 0 & 0 \\
\hline CIP & 26 & 76.5 & 3 & 100 & 1 & 100 & 2 & 100 & 2 & 100 & 1 & 100 & 2 & 100 \\
\hline C & 33 & 97 & 3 & 100 & 1 & 100 & 0 & 0 & 2 & 100 & 1 & 100 & 2 & 100 \\
\hline $\mathrm{CL}$ & 0 & 0 & 0 & 0 & 0 & 0 & 0 & 0 & 0 & 0 & 0 & 0 & 0 & 0 \\
\hline TS & 13 & 38.2 & 2 & 66.7 & 1 & 100 & 0 & 0 & 2 & 100 & 0 & 0 & 0 & 0 \\
\hline $\mathrm{CN}$ & 26 & 76.5 & 2 & 66.7 & 1 & 100 & 0 & 0 & 1 & 50 & 1 & 100 & 1 & 50 \\
\hline IPM & 34 & 100 & 3 & 100 & 1 & 100 & 2 & 100 & 2 & 100 & 1 & 100 & 2 & 100 \\
\hline PRL & 0 & 0 & 0 & 0 & 0 & 0 & 0 & 0 & 0 & 0 & 0 & 0 & 0 & 0 \\
\hline $\mathrm{TE}$ & 12 & 35.3 & 2 & 66.7 & 0 & 0 & 2 & 100 & 2 & 100 & 0 & 0 & 0 & 0 \\
\hline $\mathrm{TM}$ & 34 & 100 & 3 & 100 & 1 & 100 & 2 & 100 & 2 & 100 & 1 & 100 & 1 & 50 \\
\hline
\end{tabular}

Table 3. Antibiotic susceptibility test against Staphylococcus sp. and Enterococcus sp. (ND) Not done.

\begin{tabular}{|c|c|c|c|c|c|c|c|c|}
\hline \multirow[t]{2}{*}{ Antibiotics } & \multicolumn{2}{|c|}{$\begin{array}{l}\text { E. faecalis } \\
(\mathrm{N}=3)\end{array}$} & \multicolumn{2}{|c|}{$\begin{array}{l}\text { E. faecium } \\
(\mathrm{N}=1)\end{array}$} & \multicolumn{2}{|c|}{$\begin{array}{c}\text { S. epidermides } \\
(\mathrm{N}=1)\end{array}$} & \multicolumn{2}{|c|}{$\begin{array}{c}\text { S. xylosus } \\
(\mathrm{N}=1)\end{array}$} \\
\hline & $\mathrm{N}$ & $\%$ & $\mathrm{~N}$ & $\%$ & $\mathrm{~N}$ & $\%$ & $\mathrm{~N}$ & $\%$ \\
\hline $\mathrm{AK}$ & ND & - & ND & - & 1 & 100 & 1 & 100 \\
\hline $\mathrm{AM}$ & 2 & 66.7 & 0 & 0 & ND & - & ND & - \\
\hline C & 3 & 100 & 1 & 100 & 1 & 100 & 1 & 100 \\
\hline $\mathrm{CC}$ & ND & - & ND & - & 0 & 0 & 1 & 100 \\
\hline CIP & ND & - & ND & - & 1 & 100 & 1 & 100 \\
\hline $\mathrm{CN}$ & ND & - & ND & - & 1 & 100 & 1 & 100 \\
\hline DO & 1 & 33.3 & 0 & 0 & ND & - & ND & - \\
\hline $\mathrm{E}$ & 0 & 0 & 0 & 0 & 0 & 0 & 0 & 0 \\
\hline $\mathrm{P}$ & 3 & 100 & 1 & 100 & 1 & 100 & 1 & 100 \\
\hline RA & 1 & 33.3 & 0 & 0 & 1 & 100 & 1 & 100 \\
\hline $\mathrm{TE}$ & ND & - & ND & - & 1 & 100 & 1 & 100 \\
\hline $\mathrm{TM}$ & ND & - & ND & - & 1 & 100 & 0 & 0 \\
\hline TS & ND & - & ND & - & 1 & 100 & 1 & 100 \\
\hline VA & 3 & 100 & 1 & 100 & 1 & 100 & 1 & 100 \\
\hline
\end{tabular}

within a typical healthy human's gut including various bacterial strains-both pathogenic (no-friendly) and non-pathogenic (friendly). They inhabit this chal- 
lenging but nutrient rich niche have adapted extremely well, where human would struggle to survive without them. Previous studies have suggested that our friendly bugs secrete chemicals that prevent the pathogenic bacteria from taking control [19]. Eleven types of bacteria identified in this study were subject to antimicrobial test using common antibiotics which are prescribed by Clinical and Laboratory Standards Institute [18]. Other species of bacteria were isolated, i.e. Bacteroides sp, Salmonella typhi, Peptostreptococcus, Clostridium perfringns bacteria were isolated [14] have not been isolated in the present work. However, due to current limited techniques available in our laboratories only limited number of bacteria was detectable. This study showed that generally all the bacteria isolated from the appendix samples were both gram positive $(11.77 \%)$ and gram negative $(88.23 \%)$. The majority of the bacteria species isolated from appendix samples, cultured and identified were found to be Escherichia coli which is in agreement with some recent studies [20] [21] [22]. The frequency of Klebsiella pneumoniae appeared less in comparison with other similar studies [23] [24]. A single isolate per of Raoultella terrigena and Serratia fonticola, were found in our study while no previous references had tackled their species in appendices; however, the Raoultella terrigena is a rarely isolatable bacterium from clinical specimens [25]. Our work included description of Citrobacter youngae with very low proportion; while Citrobacter (Citrobacter freundii), instead, was isolated in another study [26]. This may refer that this species is the first time to be isolated in appendix. The low rate of Enterobacter cloacae found in our study was almost similar to other two previous studies, respectively [20] [26].

Amongst the gram positive bacteria species Staphylococcus and Enterococcus isolated, another species, e.g. Staphylococcus xylosus has also been isolated with a very low rate may indicate as if it is an incipience isolate found in the city of Kirkuk (Salman, 2017, Personal communication) while the Staphylococcus epidermidis described in the present work had a close rate to another study [23]. Out of 50 samples only the Enterococcus faecalis and Entercoccus faecium were isolated with low proportions in comparison with two recent studies [21] [24].

The implication of the role of all above bacteria isolated from appendicitis is yet dubious with an unclear pathogenecity function so far while the role of other micro-organism might also be expected. Although the isolated bacteria are classified by other bacteriologists as normal flora but they might have been participated in pathogenicity of the appendicitis. Generally, the variations in the ratio and in the type of bacteria isolated in current study in comparison with others could be due to a few reasons, i.e. higher number of the specimens encountered in other studies and the methodology of isolation and culturing involved. Our single negative culture may be a consequence of other microorganism, i.e. anaerobic bacteria which need a longer anaerobic incubation period to ensure its growth and identification. Therefore, perhaps more samples of appendices are necessary to drive a righteous conclusion on the habitats and role of other micro-organisms with more antibiotics to test for an overall a precise analysis. 
Medical experiences postulate that antibiotics used for treatment appendicitis may equally be effective in certain cases of non-ruptured appendicitis [27]. The results showed that both Imipenem and Amikacin are effective antibiotics against all gram negative bacilli isolates. The latter is in concomitant with a recent work where both Imipenem and Amikacin were well effective against gram negative bacilli [28]. The E. coli isolates in our specimens showed various degrees of resistance to Ciprofloxacin, Co-trimoxazole, Tetracycline, Gentamicin which is in agreement with a similar study where $E$. coli resisted to these antibiotics with a slight differences [29]. While all stains of $E$ coli showed resistance against Ceftazidime, Augmentin, Ampicillin, Piperacillin, Cephalothin; however, some stains showed resistance against Cefixime, Azteroname, Chloramphenicol and Cefotaxime. Similar results, with a subtle difference, were found elsewhere too [30] [31] [32] [33].

The resistance of some strains of $K$. pneumoniae to Co-trimoxazole, Tetracycline, Gentamicin, Piperacillin, Ceftazidime, Ampicillin, Azteroname, Augmentin Gentamicin and Cephalothinin found in our study was in agreement with most recent studies [34] [35] [36] [37]. The resistance of Enterobactor cloacae against Piperacillin, Ceftazidime, Ampicillin, Augmentin, Cephalothin was similar to another study in Egypt [31]. Our Citrobacter youngae, showed resistance to almost all the antibiotics tested are in concomitant with some recent studies [38] [39] [40]. The Pseudomonas aeruginosa was resistance to Piperacillin, Ceftazidime, Ampicillin, Azteroname, Augmentin and Cephalothin [31] [36].

Generally, the gram positive bacteria encountered here showed sensitivity to both antibiotics Penicillin and Vancomycin [41]. However, Enterococcus faecalis showed moderate sensitivity to Ampicillin with little sensitive to Rifampin but with subtile variations [26]. The E. faecalis showed sensitivity to Doxycycline and resistance to Erythromycin similar to those of Pinheiro and co-workers [42] while our Staphylococcus epidermides was sensitive to Gentamycin, Ciprofloxacin, Chloramphenicol, Rifampin, Amikacin and Tobramycin [43]; and the Staphylococcus xylosus showed resistance to Erythromycin; however, both bacteria resisted Erythromycine [44]. The variation in the resistance of bacteria to antibiotics depends upon species to another and strain to another due to different mechanism of action against antibiotics.

\section{Conclusion}

The frequency of the gram positive habitat bacteria in the appendix were almost 1:4 of the gram negative with E. coli as the highest bacteria followed by other species with low proportion. The bacteria Citrobacter youngae was more resistant to antibiotics than other described species. The effectiveness of antibiotics, i.e. Amikacin, Tobramycin and Imipenem are specific against gram negative bacilli while Penicillin and Vancomycin against gram positive.

\section{References}

[1] Smith, H.F., Fisher, R.E., Everett, M.L., Thomas, A.D., Bollinger, R.R. and Parker, 
W. (2009) Comparative Anatomy and Phylogenetic Distribution of the Mammalian Cecal Appendix. Evolutionary Biology, 22, 1984-1999. https://doi.org/10.1111/j.1420-9101.2009.01809.x

[2] Laurin, M., Everett, M.L. and Parker, W. (2011) The Cecal Appendix: One More Immune Component with a Function Disturbed by Past-Industrial Culture. Anatomical Record, 294, 567-579. https://doi.org/10.1002/ar.21357

[3] Carr, N.J. (2000) The Pathology of Acute Appendicitis. Annual Diagnostic Pathology, 4, 46-58. https://doi.org/10.1016/S1092-9134(00)90011-X

[4] Gwynn, L.K. (2001) The Diagnosis of Acute Appendicitis: Clinical Assessment versus Computed Tomography Evaluation. Journal of Emergency Medicine, 21, 119 123. https://doi.org/10.1016/S0736-4679(01)00353-5

[5] Petroianu, A. (2012) Acute Appendicitis: Propedeutics and Diagnosis. International Journal of Surgery, 10, 115-11A9.

[6] D'Souza, N. and Nugent, K. (2016) Appendicitis. American Family Physician, 93, 142-143.

[7] Swidsinski, A., Dörffel, Y., Loening-Baucke, V., et al. (2011). Acute Appendicitis Is Characterized by Local Invasion with Fusobacterium Nucleatum/Necrophorum. Gut, 60, 34-40. https://doi.org/10.1136/gut.2009.191320

[8] Baron, E.J., Bennion, R., Thompson, J., et al. (1992) A Microbiological Comparison between Acute and Complicated Appendicitis. Clinical Infectious Disease, 14, 227 231. https://doi.org/10.1093/clinids/14.1.227

[9] Lari, J., Kirk, D. and Howden, R. (1976) Bacteriological Survey of Acute Appendicitis in Children, British Journal of Surgery, 63, 643-646. https://doi.org/10.1002/bjs.1800630821

[10] Piper, R., Kalger, L. and Tidefell, U. (1982) Theory of Bacteroides fragilis in Pathogenesis of Acute Appendicitis. Acta Chirurgica Scandinavica, 148, 39-44.

[11] Lau, W.Y., Teo-chan, C.H., Fan, S.T., et al. (1984) The Bacteriology and Septic Complication of Patients with Appendicitis. Annual Surgery, 200, 576-581. https://doi.org/10.1097/00000658-198411000-00003

[12] Roberts, J.P. (1988) Quantitative Bacterial Flora of Acute Appendicitis. Archives of Disease in Childhood, 63, 536-540.

[13] Rains, A.J.H. and Capper, W.M. (1988) Baily and Loves Short Practice of Surgery. 20th Edition. HL Lewis and Co. Ltd., London.

[14] Naher, H.S. and Katab, F.K. (2013) Bacterial Profile Associated with Appendicitis. International Research Journal of Medical Sciences, 1, 1-4.

[15] Simpson, J., Samaraweera, A.P., Sara, R.K. and Lobo, D.N. (2008) Acute Appendicitis-A Benign Disease? Annals of the Royal College of Surgeons of England, 90, 313-316. https://doi.org/10.1308/003588408X285973

[16] Andreu-Ballester, J.C., Gonzales-Sanchez, A., Ballester, F., et al. (2009) Epidemiology of Appendectomy and Appendicitis in Valencian Community (Spain), 1998-2007. Digestive Surgery, 26, 406-412. https://doi.org/10.1159/000235956

[17] Annual Health Report (2013) Department of Epidemiology \& Medical Statistical. Hamad Medical Corporation, Doha (Qatar).

[18] Clinical and Laboratory Standards Institute (CLSI) (2016) Performance Standards for Antimicrobial Susceptibility Testing. 26th Edition, Wayne.

[19] Nordqvist, C. (2013) Antibiotic Treatment Can Be Followed by Intestinal Infections. Why? https://www.medicalnewstoday.com/articles/265506.php

[20] Borhan, G.H. (2006) Bacteriological and Pathohistological Study on Appendicitis. 
MSc Thesis, Faculty of Science, Al-Mustansiriya University, Baghdad.

[21] Hasola, D.J., Dutta, R., Darrell, C., Gende, G., Kaptigau, W., Liko, O. and Kevau, I. (2012) The Bacterial Flora of Acute Appendicitis at the Port Moresby General Hospital in Papua New Guinea. PNG Medical Journal, 55, 12-15.

[22] Richardsen, I., Schöb, D., Ulmer, T., Steinau, G., Neumann, U., Klink, C. and Lambertz, A. (2015) Etiology of Appendicitis in Children: The Role of Bacterial and Viral Pathogens. Journal of Investigative Surgery, 29, 74-79. https://doi.org/10.3109/08941939.2015.1065300

[23] Abdulrahman, M. (2003) Bacteriological Study of Acute Appendicitis. IJGE, 1, 33-40.

[24] Chao, C.T., Lee, S.Y., Yang, W.S., Chen, H.W., Fang, C.C., Yen, C.J., Chih-Chiang, K., Hung, K.Y. and Huang, J.W. (2013) Citrobacter Peritoneal Dialysis Peritonitis: Rare Occurrence with Poor Outcomes. International Journal of Medical Sciences, 10, 1092-1098. https://doi.org/10.7150/ijms.6251

[25] Izard, D., Ferragut, C., Gavini, F., Kersters, K., De Ley, J. and Leclerc, H. (1981) Klebsiella terrigena, a New Species from Soil and Water. International Journal of Systematic Bacteriology, 31, 116-127. https://doi.org/10.1099/00207713-31-2-116

[26] Karim, A.K. (2003) Microbiology of Clinically Suspected Appendicitis in Rizgary Teaching Hospital-Erbil. MSc Thesis, Faculty of Science, University of Salahaddin-Erbil.

[27] Varadhan, K.K., Neal, K.R. and Lobo, D.N. (2012) Safety and Efficacy of Antibiotic Compared with Appendectomy for Treatment of Uncomplicated Acute Appendicitis: Meta-Analysis of Randomized Controlled Trials. BMJ, 344, e2156.

[28] Lob, S., Hackel, M., Kazmierczak, K., Hoban, D., Young, K., Motyl, M., Karlowsky, J. and Sahm, D. (2017) In Vitro Activity of Imipenem-Relebactam against Gram-Negative Bacilli Isolated from Patients with Lower Respiratory Tract Infections in the United States in 2015-Results from the SMART Global Surveillance Program. Diagnostic Microbiology and Infectious Disease, 88, 171-176.

[29] Kibret, M. and Abera, B. (2011) Antimicrobial Susceptibility Patterns of E. coli from Clinical Sources in Northeast Ethiopia. African Health Sciences, 11, 40-45. https://doi.org/10.4314/ahs.v11i3.70069

[30] Ahmed, K.H. (2016) A Bacteriological and Immnological Study of Individuals Infected with Urinary Tract Infection in Kirkuk City. MSc Thesis, Faculty of Science, University of Kirkuk, Kirkuk.

[31] Ashour, H. and El-Sharif, A. (2009) Species Distribution and Antimicrobial Susceptibility of Gram-Negative Aerobic Bacteria in Hospitalized Cancer Patients. Journal of Translational Medicine, 7, 9-13.

[32] Sood, S. (2016) Chloramphenicol-A Potent Armament against Multi-Drug Resistant (MDR) Gram Negative Bacilli? Journal of Clinical and Diagnostic Research, 10, $1-3$.

[33] Moghaddam, M., Zolfaghari, M. and Hoseini, N. (2017) CTX-M-15 Type B-Lactamases from Clinical Isolates of Escherichia coli by Polymerase Chain Reaction and DNA Sequencing. Zahedan Journal of Research in Medical Sciences, 19, e5814.

[34] Abdel Rahim, K. and Mohamed, A. (2014) Prevalence of Extended Spectrum $\beta$-lactamase-Producing Klebsiella pneumoniae in Clinical Isolates. Jundishapur Journal of Microbiology, 7, 17114.

[35] Lin, W., Wang, J., Chang, S., Chang, F., Fung, C.H., Chuang, Y., Chen, Y., Shiau, Y., 
Tan, M., Wang, H., Lai, J., Huang, W. and Lauderdale, T. (2016) The Antimicrobial Susceptibility of Klebsiella pneumoniae from Community Settings in Taiwan, a Trend Analysis. Scientific Reports, 6, Article No. 36280. https://doi.org/10.1038/srep36280

[36] Mohammed, M., Alnour, T., Shakurfo, O. and Aburass, M. (2016) Prevalence and Antimicrobial Resistance Pattern of Bacterial Strains Isolated from Patients with Urinary Tract Infection in Messalata Central Hospital, Libya. Asian Pacific Journal of Tropical Medicine, 9, 771-776. https://doi.org/10.1016/j.apjtm.2016.06.011

[37] Mahmoudi, S., Mahzari, M., Banar, M., Pourakbari, B., Taghi, M., Ashtiani, H., Mohammadi, M., Valian, S. and Mamis, S. (2017) Antimicrobial Resistance Patterns of Gram-Negative Bacteria Isolated from Bloodstream Infections in an Iranian Referral Paediatric Hospital: A 5.5-Year Study. Journal of Global Antimicrobial Resistance, 11, 17-22. https://doi.org/10.1016/j.jgar.2017.04.013

[38] Romanus, I., Emmanuel, N., Ngozi, A., Onyinyechi, U., Chidiebube, N., Egwu, O. and Nnenna, N. (2013) Antibiotic Susceptibility Patterns of Bacterial Isolates from Hospitalized Patients in Abakaliki. International Research Journal of Basic and Clinical Studies, 1, 46-52.

[39] Basavaraj, C.P. and Jyothi, P. (2014) Antibiotic Sensitivity Pattern of Citrobacter spp. Isolated from Patients with Urinary Tract Infections in Tertiary Care Hospital in South India. International Journal of Pharmacy and Pharmaceutical Sciences, 7, 252-254.

[40] Trojan, R., Razdan, L. and Singh, N. (2016) Antibiotic Susceptibility Patterns of Bacterial Isolates from Pus Samples in a Tertiary Care Hospital of Punjab, India. International Journal of Microbiology, 2016, Article ID: 9302692. https://doi.org/10.1155/2016/9302692

[41] Morfin-Otero, R., Noriega, E. and Dowzicky, M. (2015) Antimicrobial Susceptibility Trends among Gram-Positive and -Negative Clinical Isolates Collected between 2005 and 2012 in Mexico: Results from the Tigecycline Evaluation and Surveillance Trial. Annals of Clinical Microbiology and Antimicrobials, 14, 53-60. https://doi.org/10.1186/s12941-015-0116-y

[42] Pinheiro, E., Gomes, E., Drucker, D., Zaia, A., Ferraz, C. and Souza-Filho, F. (2004) Antimicrobial Susceptibility of Enterococcus faecalis Isolated from Canals of Root Filled Teeth with Periapical Lesions. International Endodontic Journal, 37, 756-763. https://doi.org/10.1111/j.1365-2591.2004.00865.x

[43] Al-Hadedy, N. (2015) Isolation and Identification of Some Bacterial Species from Environmen of Azadi Teaching Hospital and Studying the Effect of Some Disinfectant on Bacteria Burkholderia pseudomallei. MSc Thesis, Faculty of Science, University of Kirkuk, Kirkuk.

[44] Resch, M., Nagel, V. and Hertel, Ch. (2008) Antibiotic Resistance of Coagulase-Negative Staphylococci Associated with Food and Used in Starter Cultures. International Journal of Food Microbiology, 127, 99-104. https://doi.org/10.1016/j.ijfoodmicro.2008.06.013 